\title{
Serendipity: an interesting word
}

\author{
Minh-Hoang Nguyen \\ Ritsumeikan Asia Pacific University \\ Beppu, Oita 874-8577, Japan
}

January 16, 2022

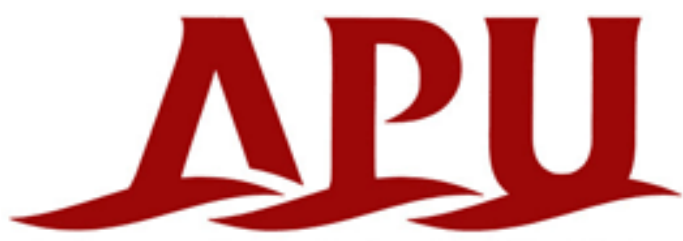

Ritsumeikan Asia Pacific University

Recently, I had a chance to work on a project about the serendipity concept using the Mindsponge information processing (Vuong, 2016; Vuong \& Napier, 2015) and 3D creativity making frameworks (Napier \& Vuong, 2013; Vuong et al., 2022; Vuong \& Napier, 2014). The word "serendipity" was coined by Horace Walpole, an English novelist and the youngest son of British Prime Minister Robert Walpole, in a letter that he wrote to his distant relative, Horace Mann. The word originated from the term "Serendip" in the fairy-tale "The Travels and Adventures of Three Princes of Serendip," which was about three princes who made discoveries of things which they were not looking for by accidents and sagacity on their adventures. The three princes in the story are sons of Jafer, king of Serendip. Serendip is the Old Persian name for Sri Lanka nowadays (Merton \& Barber, 2004). Despite appearing centuries ago, the term "serendipity" has only become fashionable, and its concept has been systematically studied by scientists quite recently.

The definition of "serendipity" is various and usually refers to chance, fate, luck, destiny, karma, coincidence, providence, etc. (Sethna, 2017). According to Merton and Barber (2004), Horace Walpole - the word's inventor - regarded serendipity as "[...] making discoveries, by accidents and sagacity, of things which they were not in quest of [...]." The Cambridge Dictionary defines it as "the fact of finding interesting or valuable things by chance." Other researchers define serendipity as an accidental or unexpected discovery of something that turns out to be valuable (Cunha et al., 2010). For instance, Denrell et al. (2003) refer to serendipity as "not just luck, but effort and luck joined by alertness and flexibility," while Andel (1994) think of it as "the art of making an unsought finding." 
I, personally, think that serendipity is an interesting word due to not only its intrinsic values but also discoveries and ideas related to serendipitous moments that I can observe around me (Nguyen et al., 2021; Vuong, 2018, 2020, 2021, 2022).

\section{References}

Andel PV. (1994). Anatomy of the unsought finding. serendipity: Orgin, history, domains, traditions, appearances, patterns and programmability. The British Journal for the Philosophy of Science, 45(2), 631-648.

Cunha MP, Clegg SR, Mendonça S. (2010). On serendipity and organizing. European Management Journal, 28(5), 319-330. https://doi.org/10.1016/j.emj.2010.07.001

Denrell J, Fang C, Winter SG. (2003). The economics of strategic opportunity. Strategic management journal, 24(10), 977-990.

Merton RK, Barber E. (2004). The Travels and Adventures of Serendipity : A Study in Sociological Semantics and the Sociology of Science. Princeton University Press.

Napier N, Vuong QH. (2013). Serendipity as a Strategic Advantage? In T. Wilkinson (Ed.), Strategic Management in the 21st Century (pp. 175-199). Praeger/ABCClio.

Nguyen MH, et al. (2021). Alice in Suicideland: Exploring the Suicidal Ideation Mechanism through the Sense of Connectedness and Help-Seeking Behaviors. International Journal of Environmental Research and Public Health, 18(7), 3681. https://doi.org/https://doi.org/10.3390/ijerph18073681

Sethna Z. (2017). Editorial. Journal of Research in Marketing and Entrepreneurship, 19(2), 201-206. https://doi.org/10.1108/jrme-11-2017-0048

Vuong QH. (2016). Global Mindset as the Integration of Emerging Socio-Cultural Values Through Mindsponge Processes: A Transition Economy Perspective. In J. Kuada (Ed.), Global Mindsets: Exploration and Perspectives (pp. 109-126). Routledge.

Vuong QH. (2018). The (ir)rational consideration of the cost of science in transition economies. Nature Human Behaviour, 2, 5. https://doi.org/10.1038/s41562-017$0281-4$

Vuong QH. (2020). Reform retractions to make them more transparent [World View]. Nature, 582, 149. https://doi.org/10.1038/d41586-020-01694-x

Vuong QH. (2021). The semiconducting principle of monetary and environmental values exchange. Economics and Business Letters, 10(3), 284-290. https://doi.org/10.17811/ebl.10.3.2021.284-290

Vuong $\mathrm{QH}$, et al. (2022). Covid-19 vaccines production and societal immunization under the serendipity-mindsponge-3D knowledge management theory and conceptual framework. Humanities and Social Sciences Communications, 9, forthcoming.

Vuong QH. (2022). A New Theory of Serendipity: Nature, Emergence and Mechanism. Berlin, Germany: De Gruyter.

Vuong QH, Napier NK. (2015). Acculturation and global mindsponge: an emerging market perspective. International Journal of Intercultural Relations, 49, 354-367. 
Vuong QH, Napier NK. (2014). Making creativity: the value of multiple filters in the innovation process. International Journal of Transitions and Innovation Systems, 3(4), 294-327. 